\title{
Fungi colonising oak seedlings (Quercus robur L.) in forest plantations in north-eastern Poland
}

\author{
Alicja Gorzkowska ${ }^{1} \bowtie$, Agnieszka Pszczótkowska ${ }^{1}$, Adam Okorski ${ }^{1}$, Justyna A. Nowakowska², \\ Tomasz Oszako ${ }^{3}$ \\ ${ }^{1}$ University of Warmia and Mazury in Olsztyn, Department of Entomology, Phytopathology and Molecular Diagnostics, \\ Plac Łódzki 5, 10-727 Olsztyn, Poland, phone +4889 5333492, e-mail: alicja.gorzkowska.uwm@gmail.com \\ ${ }^{2}$ Forest Research Institute, Laboratory of Molecular Biology, Sękocin Stary, Braci Leśnej 3, 05-090 Raszyn, Poland \\ ${ }^{3}$ Białystok University of Technology, Forest Faculty in Hajnówka, 17-200 Hajnówka, Poland
}

\section{Abstract}

Fungi colonising oak seedlings in forest plantations in north-eastern Poland were identified in 2014-2015. The evaluated 4- to 6-year bare root oaks originated from the Olsztynek Forest District (Regional Directorate of the State Forests in Olsztyn). In total, 744 fungal isolates belonging to 11 different species, and 11 genera, were identified in tested plants. Amongst them, 186 cultures (25\%) were classified as plant pathogens. The most commonly isolated pathogenic fungi belonged to the Fusarium and Cylindrocarpon genera.

\section{KeY WORDS}

diseases, forest cultivation, fungi, Fusarium, Cylindrocarpon, oak

\section{INTRODUCTION}

The predominance of coniferous trees in Polish forests contributes to soil acidification and podzolisation, which significantly decreases soil quality. The introduction of greater numbers of broadleaved species to forests can substantially improve soil condition as part of a biological reclamation scheme (Gniot 2007).

Pedunculate oaks are commonly encountered in Central Europe, and they are one of the most important native species of deciduous trees (Nowakowska et al. 2007; Szewczyk et al. 2015). Oaks play a very important role in forest ecosystem and in its economy because of their valuable wood (Pietras et al. 2015). Oak stands oc- cupy approximately 6\% of Polish forests (Szewczyk and Czeryba 2010), and this area is expected to increase under Poland's new forest policy (Banach 2011). In 2014, fungal diseases were reported on a forest area of 208,305,000 ha. The predominant infectious diseases were root diseases (163,000 ha, $78.3 \%$ of total infected area), and the decline of deciduous trees was observed in an area of 10200 ha. In 2014, oak stand decline spanned an area of 2,295 ha (Zajączkowski et al. 2015). Generally, oaks are colonised by various pathogens, which decrease the assimilation rate and reduce the chlorophyll concentrations (Heuser and Zimmer 2002). In past two decades, a significant drop in oak populations across Europe and North America was reported by many authors (Rizzo et 
al. 2002; Jönsson et al. 2005; McPherson et al. 2013). The main symptoms of disease are crown thinning, leaf discoloration and chlorosis, shoot death and bark damage (Jönsson et al. 2005). In Europe, oak stands have been declining steadily over the past 200 years (Thomas et al. 2002; Oszako 2004), and the first reports of oak decline in Poland date back to the 1950s (Oszako and Orlikowski 2005; Szewczyk and Czeryba 2010). According to different authors, oak death is a complex, long-term process, which leads to decrease in viability of oak stands under the exposure to stress. Stressors lower tree resistance to biotic factors (Condeso-Emiko and Meentemeyer 2007; Szewczyk et al. 2015). Fungal pathogens of the genus Phytophthora are amongst the leading biotic factors causing severe damage to oaks. Genus Phytophthora is the main cause of sudden oak death (SOD), which was responsible for the decline of many oak stands in California (Rizzo et al. 2002; Jönsson et al. 2005; McPherson et al. 2013). Sudden oak death has also been reported in Japan since 1980 (Mastuda et al. 2010). Another group of pathogens responsible for the decline of oak populations are fungal species of the genus Fusarium, mostly Fusarium solani, Fusarium oxysporum and Fusarium eumartii (Wit et al. 2015). Also, oak powdery mildew is another serious disease which is caused by Erysiphe alphitoides and affects the assimilative organs of trees in all age classes (Szewczyk et al. 2015). Damage caused by different agents (fungi, insects, secondary pathogens) can be favoured by weather conditions, including dry and hot summers (Nowakowska et al. 2007).

The aim of this study was i) to monitor fungi occurrence in different tissues of oak bare root seedlings growing in Olsztynek Forest District plantations and ii) to identify pathogens, which can cause a serious threat to the sustainable growth and development of future oak stands.

\section{Material AND MEthods}

\section{Description of research area}

The experiment was performed with bare root oak seedlings from plantations, collected in the Olsztynek Forest District (Regional Directorate of the State Forests in Olsztyn). The research area extends between 19'46'47' $\mathrm{E}$ and $20^{\circ} 29^{\prime} 4^{\prime \prime} \mathrm{E}$ and between $53^{\circ} 23^{\prime} 44^{\prime \prime} \mathrm{N}$ and $53^{\circ} 40^{\prime} 18^{\prime \prime} \mathrm{N}$. The area of the Olsztynek Forest District is characterised by a predominance of rusty soils (more than $50 \%$ of the total area) (Tab. 1). Seedlings were obtained from plantations managed by the Forest Subdistricts of Gibała and Maróz (samples collected in the third decade of May 2014 and May 2015).

Table 1. Characteristics of forest plantations and compartment area

\begin{tabular}{|c|c|c|c|c|c|}
\hline 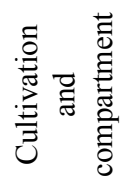 & 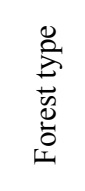 & 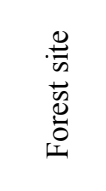 & 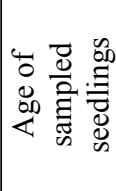 & 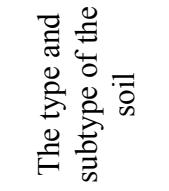 & 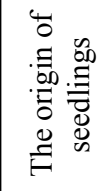 \\
\hline $\begin{array}{l}\text { Maróz } \\
\text { 408-m-00 }\end{array}$ & $\begin{array}{l}\text { Fresh } \\
\text { forest }\end{array}$ & $\begin{array}{l}\text { Post } \\
\text { agricul- } \\
\text { tural }\end{array}$ & $\begin{array}{l}5-6 \\
\text { years }\end{array}$ & $\begin{array}{l}\text { Type: } \\
\text { Rusty soils } \\
\text { Subtype: } \\
\text { Rusty } \\
\text { brown soils }\end{array}$ & $\begin{array}{l}\text { Ground } \\
\text { nursery }\end{array}$ \\
\hline $\begin{array}{l}\text { Maróz } \\
\text { 287-b-00 }\end{array}$ & $\begin{array}{l}\text { Fresh } \\
\text { mixed } \\
\text { forest }\end{array}$ & Natural & $\begin{array}{l}4-5 \\
\text { years }\end{array}$ & $\begin{array}{l}\text { Type: } \\
\text { Brown soils } \\
\text { Subtype: } \\
\text { Brown } \\
\text { acidic soils }\end{array}$ & $\begin{array}{l}\text { Con- } \\
\text { tainer } \\
\text { nursery }\end{array}$ \\
\hline $\begin{array}{l}\text { Gibała } \\
38-c-00\end{array}$ & $\begin{array}{l}\text { Fresh } \\
\text { forest }\end{array}$ & Natural & $\begin{array}{l}5-6 \\
\text { years }\end{array}$ & $\begin{array}{l}\text { Type: } \\
\text { Rusty soils } \\
\text { Subtype: } \\
\text { Rusty } \\
\text { brown soils }\end{array}$ & $\begin{array}{l}\text { Ground } \\
\text { nursery }\end{array}$ \\
\hline
\end{tabular}

Table 2. Monthly averages of daily temperature and monthly precipitation totals in 2013 and 2014

\begin{tabular}{|l|c|c|c|c|c|c|}
\hline \multirow{3}{*}{ Month } & \multicolumn{6}{|c|}{ Year } \\
\cline { 2 - 7 } & 2013 & 2014 & 2015 & 2013 & 2014 & 2015 \\
\cline { 2 - 7 } & $\begin{array}{c}\text { Monthly averages of } \\
\text { daily temperature }\left[{ }^{\circ} \mathrm{C}\right]\end{array}$ & \multicolumn{3}{|c|}{$\begin{array}{c}\text { Monthly precipitation } \\
\text { totals [mm] }\end{array}$} \\
\hline January & -4.69 & -4.05 & 0.45 & 51.0 & 49.7 & 35.8 \\
\hline February & -1.32 & 0,48 & -0.29 & 239.9 & 27.2 & 18.5 \\
\hline March & -2.99 & 5.39 & 4.29 & 59.7 & 58.8 & 40.6 \\
\hline April & 5.80 & 9.52 & 7.22 & 64.7 & 21.6 & 41.3 \\
\hline May & 14.94 & 13.50 & 12.15 & 35.2 & 27.9 & 27.2 \\
\hline June & 17.84 & 15.21 & 15.77 & 72.1 & 64.0 & 23.4 \\
\hline July & 18.2 & 20.66 & 17.74 & 90.6 & 122.8 & 15.0 \\
\hline August & 17.64 & 16.36 & 21.09 & 63.0 & 99.3 & 15.3 \\
\hline September & 11.21 & 13.76 & 14.25 & 102.1 & 30.0 & 12.4 \\
\hline October & 8.80 & 8.65 & 9.01 & 11.6 & 8.5 & 10.8 \\
\hline November & 4.47 & 3.51 & 4.36 & 31.1 & 121.9 & 45.4 \\
\hline December & 1.76 & -0.59 & 1.25 & 37.1 & 66.2 & 23.4 \\
\hline
\end{tabular}




\section{Weather conditions}

Meteorological data come from a measuring station in Mielno, located within the Olsztynek Forest District (Tab. 2).

\section{Laboratory Analyzes}

Fifteen oak seedlings were randomly selected from each cultivation and separated into roots, leaves and shoots. Tissue fragments were disinfected with $70 \%$ ethanol and $1 \%$ sodium hypochlorite. Disinfected material was separated into $0.5 \mathrm{~cm}$ sections with a scalpel in a laminar flow chamber, and it was placed on Petri plates containing potato dextrose agar (PDA). Ten root, shoot and leaf sections were placed on each plate, incubated at $23^{\circ} \mathrm{C}$ for 14 days. Sections from every variant of a given sample were placed on 15 Petri plates. After 14 days of incubation, the emerged fungal colonies were viewed under a light microscope. Fungi were identified to the genus and species level based on such structures as macroconidia, sporodochia, chlamydospores and spores with the use of fungal identifi- cation keys developed by Booth (1971), Kwaśna et al. (1991), Ellis (1971), Gerlach and Nirenberg (1982), and Kröber (1985).

\section{Results}

The quantitative and qualitative composition of isolated fungi was very similar in both years of the study. A total of 744 fungal isolates, including 186 pathogenic fungal cultures $(25 \%)$, belonging to different genera and species were identified. The species Alternaria alternata and the genus Epicoccum constituted the largest groups of saprotrophic fungi, whereas fungi of the genera Fusarium and Cylindrocarpon were the most prevalent pathogens that accounted for $37 \%$ and $35.5 \%$ of all isolates, respectively. The highest number of fungal cultures was isolated from roots (297 isolates), whereas leaves were least colonised by fungi (156 isolates). A total of 291 isolates were obtained from shoots (Tab. 3 and 4).

Table 3. Fungi colonizing the tissues of oak seedlings in 2014

\begin{tabular}{|c|c|c|c|c|c|c|c|c|c|c|c|c|}
\hline \multirow{3}{*}{ No. } & \multirow{3}{*}{ Fungal species/genus } & \multicolumn{9}{|c|}{ Nursery } & \multirow{3}{*}{ Total } & \multirow{3}{*}{$\%$} \\
\hline & & \multicolumn{3}{|c|}{$\begin{array}{l}\text { Gibała Forest District } \\
\text { 38-c-00 }\end{array}$} & \multicolumn{3}{|c|}{$\begin{array}{c}\text { Maróz Forest District } \\
\text { 287-b-00 }\end{array}$} & \multicolumn{3}{|c|}{$\begin{array}{l}\text { Maróz Forest District } \\
408-\mathrm{m}-00\end{array}$} & & \\
\hline & & Root & Leaf & Shoot & Root & Leaf & Shoot & Root & Leaf & Shoot & & \\
\hline 1 & 2 & 3 & 4 & 5 & 6 & 7 & 8 & 9 & 10 & 11 & 12 & 13 \\
\hline 1. & $\begin{array}{l}\text { Alternaria alternata (Fr.) } \\
\text { Keissler }\end{array}$ & & & & & 6 & 42 & & & & 48 & 14.0 \\
\hline 2. & Aureobasidium spp. & & 3 & & 3 & & & & & & 6 & 1.8 \\
\hline 3. & Botrytis cinerea Pers. & & 18 & & & 3 & & & & & 21 & 6.0 \\
\hline 4. & Cladosporium spp. & & & & 18 & 6 & & 3 & 3 & & 30 & 8.7 \\
\hline 5. & Cylindrocarpon spp. & 15 & & & 12 & & & 3 & & & 30 & 8.7 \\
\hline 6. & Epicoccum spp. & & & & 3 & 6 & 21 & & & 6 & 36 & 10.6 \\
\hline 7. & $\begin{array}{l}\text { Erysiphe alphitoides } \\
\text { (Griffon \& Maubl.)* }^{*}\end{array}$ & & & & & 6 & & & & & 6 & 1.8 \\
\hline 8. & Fusarium avenaceum (Fr.) & & & & & & 6 & & & & 6 & 1.8 \\
\hline 9. & Fusarium oxysporum Schltdl. & & & & & 3 & & & & & 3 & 0.9 \\
\hline 10. & Fusarium sambucinum Fuckel. & & & & & & 3 & & & & 3 & 0.9 \\
\hline 11. & Fusarium solani (Mart.) Sacc. & & & & & 3 & & & & & 3 & 0.9 \\
\hline 12. & Mortierella spp. & & & & 3 & & & & & & 3 & 0.9 \\
\hline 13. & Penicillium spp. & & & & 3 & 6 & & 6 & 6 & 3 & 24 & 7.0 \\
\hline 14. & Periconia spp. & 3 & & & & & & & & & 3 & 0.9 \\
\hline
\end{tabular}




\begin{tabular}{|c|c|c|c|c|c|c|c|c|c|c|c|c|}
\hline 1 & 2 & 3 & 4 & 5 & 6 & 7 & 8 & 9 & 10 & 11 & 12 & 13 \\
\hline 15. & Rhizopus spp. & & & & 12 & & & & 12 & 21 & 45 & 13.2 \\
\hline 16. & Rhizopus spp. & & & & & & & 9 & & & 9 & 2.6 \\
\hline 17. & Trichoderma spp. & 3 & & 9 & & & & 36 & 3 & 9 & 60 & 17.5 \\
\hline 18. & $\begin{array}{l}\text { Zygorhynchus heterogamus } \\
\text { (Vuill.) }\end{array}$ & & & & 6 & & & & & & 6 & 1.8 \\
\hline \multicolumn{2}{|c|}{ Total number of fungal cultures } & 21 & 21 & 9 & 60 & 39 & 72 & 57 & 24 & 39 & 342 & 100 \\
\hline
\end{tabular}

* Cultures observed directly on tissues.

Table 4. Fungi colonizing the tissues of oak seedlings in 2015

\begin{tabular}{|c|c|c|c|c|c|c|c|c|c|c|c|c|}
\hline \multirow{3}{*}{ No. } & \multirow{3}{*}{ Fungal species/genus } & \multicolumn{9}{|c|}{ Nursery } & \multirow{3}{*}{ Total } & \multirow{3}{*}{$\%$} \\
\hline & & \multicolumn{3}{|c|}{$\begin{array}{l}\text { Gibała Forest District } \\
\text { 38-c-00 }\end{array}$} & \multicolumn{3}{|c|}{$\begin{array}{l}\text { Maróz Forest District } \\
\text { 287-b-00 }\end{array}$} & \multicolumn{3}{|c|}{$\begin{array}{l}\text { Maróz Forest District } \\
\text { 408-m-00 }\end{array}$} & & \\
\hline & & Root & Leaf & Shoot & Root & Leaf & Shoot & Root & Leaf & Shoot & & \\
\hline 1. & Acremonium spp. & & & & 9 & & & & & & 9 & 2.2 \\
\hline 2. & $\begin{array}{l}\text { Alternaria alternata (Fr.) } \\
\text { Keissler }\end{array}$ & 33 & & 24 & 3 & 3 & 12 & & 6 & 6 & 87 & 21.6 \\
\hline 3. & Aureobasidium spp. & & & & & & & 3 & & 3 & 6 & 1.6 \\
\hline 4. & Cladosporium spp. & 3 & & & & & & & 3 & 3 & 9 & 2.2 \\
\hline 5. & Colletotrichum spp. & & 3 & & & & & & & & 3 & 0.7 \\
\hline 6. & Cylindrocarpon spp. & 27 & & & & & & 3 & & 6 & 36 & 9.0 \\
\hline 7. & Epicoccum spp. & 3 & & 6 & & & 6 & 9 & & 6 & 30 & 7.5 \\
\hline 8. & $\begin{array}{l}\text { Erysiphe alphitoides } \\
\text { (Griffon \& Maubl.)* }^{*}\end{array}$ & & & & & & & & 12 & & 12 & 3.0 \\
\hline 9. & Fusarium avenaceum (Fr.) & & & 9 & & & 18 & 3 & & 9 & 39 & 9.7 \\
\hline 10. & Fusarium oxysporum Schltdl. & & & & & & & & & 9 & 9 & 2.2 \\
\hline 11. & $\begin{array}{l}\text { Fusarium poae (Peck) } \\
\text { Wollenw. }\end{array}$ & & & 3 & & & & & & & 3 & 0.7 \\
\hline 12. & Fusarium solani (Mart.) Sacc. & & & & & & & & & 3 & 3 & 0.7 \\
\hline 13. & Penicillium spp. & 6 & & & 33 & 9 & & 12 & 9 & & 69 & 17.2 \\
\hline 14. & Periconia spp. & & & & & 6 & & & & & 6 & 1.6 \\
\hline 15. & Rhizopus spp. & & 12 & 15 & & & & & & 6 & 33 & 8.2 \\
\hline 16. & Spadicoides atra (Corda) & & & 3 & & & & & 6 & & 9 & 2.2 \\
\hline 17. & Rhizopus spp. & & & & 9 & & 9 & 3 & & & 21 & 5.2 \\
\hline 18. & Trichoderma spp. & & & 3 & & & & & 3 & 12 & 18 & 4.5 \\
\hline Total & number of fungal cultures & 72 & 15 & 63 & 54 & 18 & 45 & 33 & 39 & 63 & 402 & 100 \\
\hline
\end{tabular}

* Cultures observed directly on tissues.

Seedlings sampled in 2014 were less colonised by fungi (342 cultures) than those obtained in 2015 (402 cultures). A similar relationship was observed in pathogen counts: 72 pathogenic fungi $(21 \%)$ were isolated in
2014, and 114 pathogenic fungi (28\%) were isolated in 2015 (Tab. 3 and 4). The presence of E. alphitoides was noted on leaves in two samples (cultures were identified directly on leaf tissue). Twenty-one Botrytis cinerea cultures were identified in the analysed samples (Tab. 3). 
The analyses also revealed the presence of a pathogenic fungal species of the genus Colletotrichum (Tab. 4). In 2014, the highest number of identified fungal colonies (171, 50.3\%) was observed on seedlings from the Maróz Forest District (on leaves, roots and shoots) (Tab. 3), whereas in 2015, on seedlings from the Gibała Forest District (150 colonies, 37.3\%) (Tab. 4).

\section{Discussion}

In forest management, massive decline of trees poses a very serious economic problem and a significant organisational and logistic challenge because of the high demand for timber. The detection and identification of fungal populations colonising oaks in forest cultivations contributes to our knowledge of fungal pathogens and promotes the initiation of protective measures at early stages of tree growth, preferably in plantations (Banach 2011).

Previous research into fungal colonisation of oak stands has revealed that the greatest losses are caused by pathogens of the genus Phytophthora (Rizzo et al. 2002; Oszako 2005; Oszako et al. 2007; McPherson et al. 2013; Scanu et al. 2013). In Poland, oak trees have been colonised mainly by Phytophthora quercina, Phytophthora cactorum, Phytophthora plurivora, Phytophthora cambivora and Phytophthora cinnamomi which are largely responsible for root diseases (Orlikowski et al. 2011; Jankowiak et al. 2013; Nowakowska et al. 2016). Trees become more susceptible to Phytophthora pathogens under water stress conditions (Oszako and Orlikowski 2005). Fungi colonising seedlings are identified with the use of traditional microscopic methods that are highly time consuming (Nowakowska et al. 2016), but unlike molecular methods, they support the identification of a wide range of fungi colonizing the analysed samples (Kulik et al. 2005).

In this study, genus Phytophthora was not isolated from the analysed tissue fragments, which can be attributed to their biology, the course of infection and the applied isolation method. The biology of oomycetes, including Phytophthora species, is closely linked with the aquatic environment. Periodic flooding, including torrential rain, stimulates the growth of sporangia and zoospores. Zoospores are motile spores that use a flagellum to move in water between soil particles in search of small $(<2 \mathrm{~mm})$ roots. Roots secrete substances that attract zoospores. Zoospores accumulated on roots, retract the flagellum and form cysts, which initiate the infection process. Attacked rootlets quickly die and become separated from larger roots which are marked with characteristic scars. Water depletion in soil contributes to the formation of chlamydospores and oogonia (agents of sexual reproduction), which remain dormant until favourable conditions (water saturation) appear again in the soil environment. Dormant spores are not present in plant tissues, and they cannot be isolated from healthy roots (Erwin and Ribeiro 1996; Jung et al. 1996). The water regime maintained in plantations suppresses the growth of pathogenic oomycetes but does not eliminate them. Pathogenic spores (on plant residues) remain in soil particles attached to roots and become infectious only when seedlings are planted in moist habitats. Oomycetes grow very slowly on artificial media in plastic trays, and they are often overgrown by rapidly proliferating fungal species, including members of the genus Fusarium. For this reason, their isolation requires selective PARPNH growth media with the addition of antibiotics (Balci and Halmschlager 2003; Jung et al. 2003; Oszako 2005; Oszako and Orlikowski 2005; Jankowiak et al. 2014).

In the present study, the largest group of pathogenic cultures belonged to the genus Fusarium. Wit et al. (2015) demonstrated that the shoots of declining oaks were colonised mainly by fungi of the genus Fusarium, where Fusarium avenaceum was the prevalent species, which corroborates our findings. However, F. avenace$u m$ is encountered in tree nurseries, and it influences the health of seedlings at successive stages of development (Okorski et al. 2015). In a study by Król et al. (2015), fungi of the genus Fusarium also colonised tree seeds. The type of disease caused by Fusarium fungi is determined by the tree developmental stage, and it can involve seedling blight, wilting, leaf spot and tree decline (Okorski et al. 2015).

In our study, seedlings were also abundantly colonised by fungi of the genus Cylindrocarpon, which are widespread in all parts of the world. The presence of specific Cylindrocarpon species is determined by the species of the host organism (Przybył 2002; Halmschlager and Kowalski 2004). Fungi of the genus Cylindrocarpon have been found to cause seedling blight in tree cultivations (Crosby et al. 2010; Słowiński 2011) and necrosis in other plant species (Jamali and Nasimi 2014). 
Also, the leaves of the analysed oak seedlings were colonised by E. alphitoides fungus, which causes oak powdery mildew. Infected leaves become brown, curled and dry, and colonised shoots are not lignified, which contributes to freezing in winter. According to many authors, the symptoms of oak powdery mildew are easy to identify and involve mainly white spots with powdery consistency (Mazur and Wojdyła 2010; Szewczyk et al. 2015).

The presence of particular fungal species is also dependent on habitat type and the origin of seedlings. The species composition of fungi present in various tissues differed depending on the habitat. In the case of post agricultural grounds, a significantly lower number of isolates of species of the genus Cylindrocarpon was identified in 2014 and 2015 than those in natural habitats (Tab. 3 and 4). Fungi belonging to this genus mainly occur on typical forest habitats (Słowiński 2011; Król et al. 2015).

The type of the nursery from which seedlings originated also influence the species composition of fungi. Seedlings growing in the Maróz cultivation (287-b-00) came from the container nursery (Tab. 1). In 2014, fungi belonging to the genus Fusarium were identified only on those seedlings (Tab. 3 and 4).

The temperatures during the study period in both years were similar, and monthly precipitation totals were minor compared to a long-term total (Tab. 2). Although, Mychayliv et al. (2011) showed that a course of air temperature in April, July, September and October and the total precipitation in April, June and September have a significant influence on the development of diseases, the present study showed no significant weather impact. The study areas were located within the measurement range of a single meteorological station.

Numerous pathogenic fungi were identified in this study, which points to considerable diversity of fungal species and genera colonising oak seedlings at early stages of development, suggesting on importance of fungal diversity determination for the purposes of healthy plant material production.

\section{Conclusions}

Oak bare root seedlings from forest plantations were colonised by both saprotrophic and pathogenic fungi. Pathogenic fungi were represented mainly by species of the genus Fusarium, mostly F. avenaceum. The results of this study indicate that forest cultivations are potentially exposed to colonisation by invasive fungal species, including members of the genus Cylindrocarpon and the species E. alphitoides and B. cinerea. Habitat type and origin of the seedlings have an impact on the occurrence of pathogens.

Our findings emphasise the importance of early pathogen detection in plantations. Fast and reliable methods for identifying phytopathogens in water and substrates are needed to eliminate pathogens from plant propagating material in line with the provisions of EU law. Seedlings that do not exhibit disease symptoms can be subjected to DNA tests for the needs of the certification process. A list of pathogens, other than quarantine organisms that are monitored by the authorised services, should be created for this purpose, and it should include invasive alien species of the genus Phytophthora, Hymenoscyphus fraxineus and Dothistroma spp.

\section{Acknowledgements}

This research was supported by the Ministry of Science and Higher Education of Poland as the part of statutory activities. The authors would like to thank the personnel of Olsztynek Forest District for making it possible to carry out the experiments and for their precious help throughout the experiment.

\section{References}

Banach J. 2011. Survival and height of pedunculate oak (Quercus robur L.) in Chrostowa I experimental trial in Brzesko Forest District. Leśne Prace Badawcze, 72 (1), 5-15.

Balci Y., Halmschlager E. 2003. Incidence of Phytophthora species in oak forests in Austria and their possible involvement in oak decline. Forest Pathology, 33, 157-174.

Booth C. 1971. The genus Fusarium. Commonwealth Mycological Institute Kew, Surrey, England.

Condeso-Emiko T., Meentemeyer R.K. 2007. Effects of landscape heterogeneity on the emerging forest disease sudden oak death. Journal of Ecology, 95, 364-365. 
Crosby C., Carpenter-Boggs L., Higgins S., Khadduri N. 2010. Detection and control of Fusarium oxysporum and Cylindrocarpon destructans in forest nursery soils. USDA Forest Service Proceedings, RMRS-P-62, 32-34.

Ellis M.B. 1971. Daematiaceases Hyphomycetes. Commonwealth Mycological Institute Kew, Surrey, England.

Erwin D.C., Ribeiro O.K. 1996. Phytophthora diseases worldwide. The American Phytopathological Society, St. Paul.

Gerlach W., Nirenberg H. 1982. The genus Fusarium - a picorial atlas. Mitteilungen aus der Biologischen Bundesanstalt für Land-und Forstwirtschaft, 209, 1-406.

Gniot M. 2007. The oak succession in the pine stand in the coniferous forest habitats (in Polish with English summary). Sylwan, 5, 60-72.

Heuser T., Zimmer W. 2002. Quantitative analysis of phytopathogenic ascomycota on leaves of pedunculate oaks (Quercus robus L.) by real-time PCR. FEMS Microbiology Letters, 209, 295-299.

Halmschlager E., Kowalski T. 2004. The mycobiota in nonmycorrhizal roots of healthy and declining oaks. Canadian Journal of Botany, 82 (10), 1446-1458.

Jamali S., Nasimi Z. 2014. First report of black-foot disease, caused by Cylindrocarpon destructans, on ornamental marigold (Tagetes minuta) in Iran. Journal of Plant Protection Research, 54 (2), 139-143.

Jankowiak R., Banach J., Balonek A. 2013. Susceptibility of Polish provenances and families of pedunculate oak (Quercus robur L.) to colonization by Phytophthora cambivora. Leśne Prace Badawcze, 74 (2), 161-170.

Jankowiak R., Stępniewska H., Bilański P., Kolařík M. 2014. Occurrence of Phytophthora plurivora and other Phytophthora species in oaks forests of southern Poland and their association with site conditions and the health status of trees. Folia Microbiologica (Praha), 59 (6), 531-542.

Jönsson U., Jung T., Sonesson K., Rosengren U. 2005. Relationships between health of Quercus robur, occurrence of Phytophthora species and site conditions in southern Sweden. Plant Pathology, 54, 502-511.

Jung T., Blaschke H., Neumann P. 1996. Isolation, identification and pathogenicity of Phytophthora spe- cies from declining oak stands. European Journal of Forest Pathology, 26, 253-272.

Jung T., Nechwatal J., Cooke D.E.L., Hartmann G., Blaschke M., Osswald W.F., Duncan J.M., Delatour C. 2003. Phytophthora pseudosyringae sp. nov., a new species causing root and collar rot of deciduous tree species in Europe. Mycological Research, 107, 772-789.

Kröber H. 1985. Experiences with Phytophthora de Bary and Pythium Pringsheim. Mitteilungen aus der Biologischen Bundesanstalt für Land-und Forstwirtschaft, 225, 1-175.

Król E., Machowicz-Stefaniak Z., Zimowska B., Abramczyk B., Zalewska E. 2015. Fungi inhabiting seeds of selected forest tree species (in Polish with English summary). Sylwan, 159 (2), 135-141.

Kulik T., Fordoński G., Pszczółkowska A., Płodzień K., Olszewski J. 2005. Identification of some Fusarium species from selected crop seeds using traditional method and BIO-PCR (in Polish with English summary). Acta Agrobotanica, 58 (2), 33-54.

Kwaśna M., Chełkowski J., Zajkowski P. 1991. Flora Polska. Grzyby (Mycota). Tom 22. Instytut Botaniki PAN, Warszawa- Kraków.

Mastuda J., Kimura K., Shin-ichiro I. 2010. Genetic characterization of Raffaelea quercivora isolates collected from areas of oak wilt in Japan. Mycoscience, 51, 310-316.

Mazur S., Wojdyła A. 2010. Protection of pedunculate oak against powdery mildew and its effect on plant growth. Ecological Chemistry Engineering A, 17 (9), 1141-1146.

McPherson B.A., Erbilgin N., Bonello P., Wood D.L. 2013. Fungal species assemblages associated with Phytophthora ramorum-infected coast live oaks following bark and ambrosia beetle colonization in northern California. Forest Ecology and Management, 291, 30-42.

Mychayliv O., Sierota Z., Lech P. 2011. Influence of weather conditions on assimilative apparatus diseases occurrence in young stands (in Polish with English summary). Infrastruktura $i$ Ekologia Terenów Wiejskich, 6, 81-90.

Nowakowska J., Malewski T., Tereba A., Oszako T. 2016. Rapid diagnosis of pathogenic Phytophthora species in soil by real-time PCR. Forest Pathology, in press. 
Nowakowska J., Oszako T., Bieniek J., Rakowski K. 2007. Genetic characterization in relation to the health state of oak populations in the Elblaski and Krotoszyński regions of Poland (in Polish with English summary). Leśne Prace Badawcze, 3, 33-51.

Okorski A., Pszczółkowska A., Okorska S., Fordoński G. 2015. First Report of Fagus sylvatica Infection by Fusarium avenaceum in Forest Container Cultivations in Northeastern Poland. Plant Disease, 99 (3), 420.

Orlikowski L.B., Oszako T., Ptaszek M. 2011. Menace of forest cultivations by Phytophthora species (in Polish with English summary). Sylwan, 155 (5), 322-329.

Oszako T. 2005. Menace of cultivations and stands (with special regards to alder) with Phytophthora species (in Polish with English summary). Sylwan, $6,55-61$.

Oszako T. 2004. Protection of Forests Against Pest Insects and Diseases. European Oak Decline Study Case. Forest Research Institute, Warsaw.

Oszako T., Orlikowski L.B. 2005. First data on the occurrence of Phytophthora cinnamomi on pednculate oak in Poland (in Polish with English summary). Sylwan, 10, 47-53.

Oszako T., Orlikowski L., Trzewik A. 2007. Menace of forest cultivations by Phytophthora species (in Polish). Postępy w Ochronie Roślin, 47 (2), 224-234.

Pietras M., Leski T., Rudawska M. 2015. Temporal dynamics of ectomycorrhizal community of pedunculate oak seedlings during the first year of growth in bare-root forest nursery (in Polish with English summary). Sylwan, 159 (10), 831-838.

Przybył K. 2002. Mycobiota of thin roots showing decay of Fraxinus excelsior L. young trees. Dendrobiology, 48, 65-69.
Rizzo D.M., Garbelotto M., Davidson J.M., Slaughter G.W., Koike S. 2002. Phytophthora ramorum as the cause of extensive mortality of Quercus spp. and Lithocarpus densiflorus in California. Plant Disease, 86, 205-214.

Scanu B., Linaldeddu B.T., Franceschini A., Anselmi N., Vannini A., Vettraino A.M. 2013. Occurrence of Phytophthora cinnamomi in cork oak forests in Italy. Forest Pathology, 43, 340-343.

Słowiński K. 2011. Ultraviolet radiation in reducing the blights of Scots pine (Pinus sylvestris L.) (in Polish). Inżynieria Rolnicza, 6 (131), 207-213.

Szewczyk W., Czeryba Z. 2010. Assessment of the health condition of oak on the basis of the degree of assimilation apparatus losses in oak stands of the Wołów Forest District (in Polish with English summary). Sylwan, 154 (2), 100-106.

Szewczyk W., Kuźmiński R., Mańka M., Kwaśna H., Łakomy P., Baranowska-Wasilewska M., BehnkeBorowczyk J. 2015. Occurrence of Erysiphe alphitoides in oak stands affected by flood disaster. Leśne Prace Badawcze, 76 (1), 73-77.

Thomas F.M., Blank R., Hartmann G. 2002. Abiotic and biotic factors and their interactions as causes of oak decline in Central Europe. Forest Pathology, 32, 277-305.

Wit M., Sierota Z., Oszako T., Mirzwa-Mróz E., Wakuliński W. 2015. Fusarium spp. on the aboveground organs of dying oaks-a new threat? (in Polish with English summary). Sylwan, 159 (5), 403-410.

Zajączkowski G., Jabłoński M., Jabłoński T., Małecka M., Kowalska A., Małachowska J., Piwnicki J. 2015. Report on the state of forests in Poland in 2014 (in Polish). Centrum Informacyjne Lasów Państwowych, Warsaw. 